\title{
The effects of stocking density, water exchange rate, feeding frequency and grading on size hierarchy development in juvenile Nile tilapia, Oreochromis niloticus $L$.
}

\author{
O. M. Yousif
}

Fish and Shrimp Farming Project, Abu Al Abyad, P.O. Box 372, Abu Dhabi, United Arab Emirates

\begin{abstract}
The effects of stocking density and water exchange rate on size variation of juvenile Oreochromis niloticus were studied. The fish subjected to the lowest stocking $(0.5 / \mathrm{L})$ and highest water exchange rate $(20$ times $/ \mathrm{hr})$ achieved the best $(\mathrm{p}<0.05)$ final body weight. Exposure of fish to the highest stocking density $(2 / \mathrm{L})$ and lowest water exchange rate $(5$ times/hr) resulted in the poorest $(\mathrm{p}<0.05)$ final body weight. The coefficient of variation of body weights of individuals subjected to the lowest and intermediate water exchange rates ( 5 and 10 times/hr, respectively) increased with increasing stocking density (from 0.5 to 2 fish/L). Fish subjected to the highest water exchange rate (20/Times/hr) did not show a similar consistent trend. Water-borne stresses compounded by those resulting from crowding and/or competition for food was suggested as the primary causes of size variation within treatments. Manipulation of water exchange rates to improve water quality and hence minimize the adverse effects of crowding was suggested. The influences of stocking density, feeding frequency and grading on size hierarchy development were also investigated. Stocking density and feeding frequency had an effect on size hierarchy development. The coefficient of variation of body weights of fish fed least frequently ( 2 times/day) increased with increasing stocking density (from 0.5 to 2 fish/L). The two groups fed 3 and 4 times/day showed an inverse relationship. Size hierarchy in the homogeneous size distributions was observed to reestablish within two weeks and increased steadily thereafter, whilst in the non-graded group (mixed group), a steady reduction in size variation was noted with time.
\end{abstract}

Key words: Stocking density, feeding frequency, grading, hierarchy, tilapia

\section{تأثيرات الكنالة ومعل لمنبدل الماء و عددمرات النغية و الندريج عل تكون اللمقية بين صغار ألسمك البللي النيلي}

\author{
عمرمحمد يوبف \\ مشروع تربية الأسمك و الربيل - لٔبو الأبيض -مب. 372 - لٔبوظب - الإمارل العربية المتحة
}

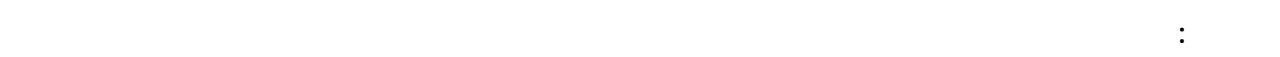

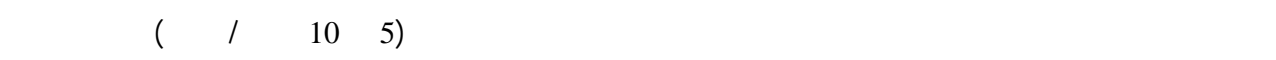

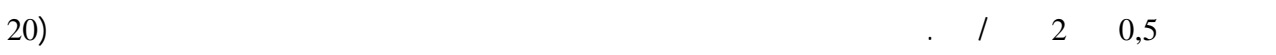

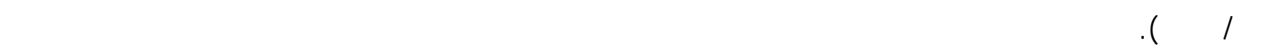

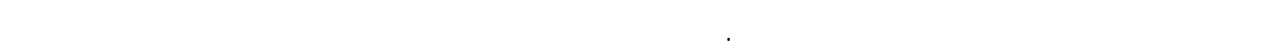

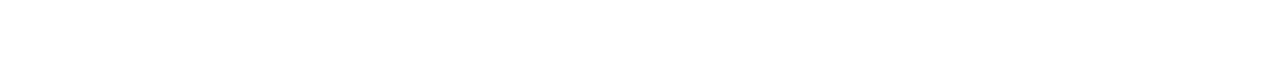

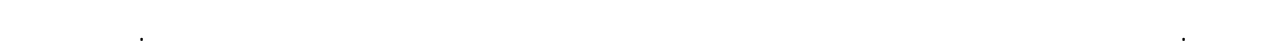

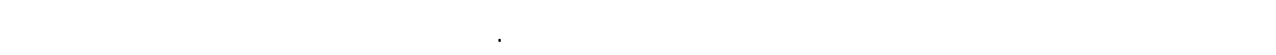

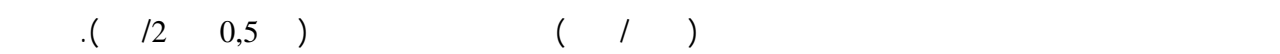

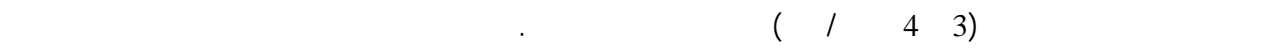

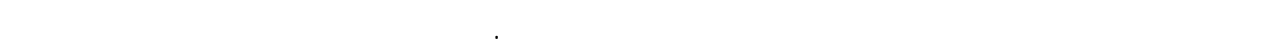

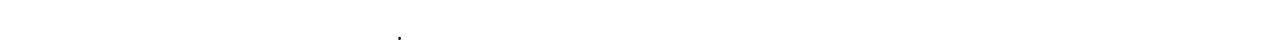

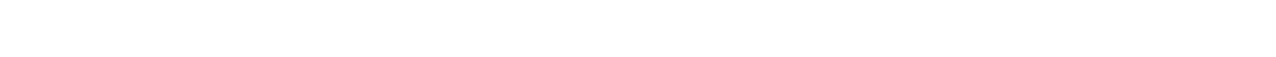
تدريج أفراد هذه المجموعة.

كالمل شفتلحية: الكثلة ، تكررار التغذية ، التدريج ، الأحجلم ، التلابيا. 


\section{Introduction}

The growth of fish kept at high stocking density is usually limited by water quality (Brett, 1979; Kjartansson et al., 1988; Bjornsson, 1994). Fish are most critically affected by build-up metabolites resulting from the biological breakdown of wastes (Spotte, 1970; Render and Stickney, 1979). To reduce the presence of such toxic products under intensive conditions, water turnover rates are usually carefully designed (Andrews et al., 1972). However, water flow rates usually cause major changes in water movement in fish rearing tanks whichin turn influence not only the cleaning efficiency but also the active metabolic rates of fish. Excessive water current speeds, resulting from high water flow rates, increase the energy requirements for swimming at the expense of growth. (Balarin and Haller, 1982).

Fish crowding may lead to the formation of a social hierarchy with the appearance of dominant and subordinate individuals (Schreck, 1981; Koebele, 1985). This socially derived stress is reflected in physiological disturbances such as the impaired growth of the subordinate individuals (Refstie and Kittelsen, 1976; Refstie, 1977; Kjartansson et al., 1988).

Size hierarchy has been documented as occurring in many fish species (Bailey et al., 1980; Keast and Edie, 1985; Paller and Lewis, 1987; Huntingford et al., 1990; Bjornsson, 1994). Ambeker and Doyle (1990) stated that variation in growth rate and relative sizes attained by individuals of a cohort in a given space is a ubiquitous phenomenon. The divergence in size among individuals of the same age has been attributed to many causes such as agonistic behavior and physiological stress (Suresh and Lin, 1992), sexual differences (Thorpe, 1977), non-sexual genetic differences (Bailey et al., 1980), food availability (Jobling, 1982; Koebele, 1985; Holm 1990), and effects of social interactions (Thorpe, 1977; Macintosh and De Silva, 1984; Dambo and Rana, 1992). The magnitude of dominance hierarchies in culture conditions is also dependent on the rates of stocking density, food distribution and water current (Alanara,1997).

To mitigate the effects of size hierarchy in fish hatcheries, size grading (sorting by fish length or weight) is often carried out (Jobling, 1983). This process may enable the small fish to grow faster once the larger fish are removed. However, the effects of size grading on reducing size variation are still inconclusive (Piper et al., 1992).

The objective of this study was to investigate the effects of stocking density and water exchange rate on size variation of juvenile Nile tilapia, Oreochromis niloticus. The influence of stocking density, feeding frequency and size grading on size hierarchy development was also examined.

\section{Materials and methods}

\section{Experimental System}

All experiments took place in indoor 14-L self-cleaning fiberglass rearing tanks. The tanks were part of a recirculating system comprising of a 200-L mechanical tank followed by two 200-L biological filter tanks and a 200-L sump tank from where water is pumped into a $300-\mathrm{L}$ header tank. Each rearing tank is equipped with a water flow valve and a double-sleeve central standpipe to control the water level and drainage. All biological, header and rearing tanks were supplied with aeration. Water temperature is thermostatically controlled at 27 $\pm 1{ }^{\circ} \mathrm{C}$ by a submerged heating device installed in the header tank.

\section{Fish}

Juvenile O. niloticus (Stirling strain) with an average body weight of $0.34 \mathrm{~g}$ were used in this study. At the beginning of each experiment, fish in each tank were carefully counted to ensure the proper stocking density, weighed and measured to the nearest $0.01 \mathrm{~g}$ and $0.01 \mathrm{~cm}$, respectively. Fish in all experiments were fed a formulated basal diet ( $40.36 \%$ crude protein, $20.25 \mathrm{~kJ} / \mathrm{g}$ diet gross energy). 


\section{Experiment 1}

This experiment was conducted to evaluate the effects of stocking density and water exchange rate. Three stocking densities of $0.5,1.0$ and 2.0 fish/L were each tested in triplicate at three water exchange rates of 5,10 and 20 times $/ \mathrm{hr}$. Initially uniform size fish were individually weighed and measured to the nearest $0.01 \mathrm{~g}$ and $0.01 \mathrm{~cm}$, respectively. During the first 6 weeks, fish were fed at a rate of $10 \%$ body weight per day and during the rest of the experimental period this allowance was reduced to $6 \%$ body weight per day. Fish were weighed biweekly and the daily ration was adjusted accordingly. In week 12, fish from each tank were individually weighed and measured to the nearest $0.01 \mathrm{~g}$ and 0.01 $\mathrm{cm}$, respectively.

The size variation of body length and weights were expressed as a coefficient of variation in percentage $((\mathrm{CV} \%=[$ s.d. of the mean weight (or length) / mean weight (or length)] $\mathrm{X}$ 100)). Water temperature $\left({ }^{\circ} \mathrm{C}\right)$, dissolved oxygen $(\mathrm{mg} / \mathrm{L})$ using Winkler method (Cox, 1990), $\mathrm{pH}$, total hardness (mg $\left.\mathrm{CaCO}_{3} / \mathrm{L}\right)$, total alkalinity $\left(\mathrm{mg} \mathrm{CaCO}_{3} / \mathrm{L}\right.$ ) and salinity (ppt) were determined weekly for the inflow water. Nitrogen-ammonia $\left(\mu \mathrm{g} \mathrm{NH} \mathrm{N}_{4}-\mathrm{N}\right)$ and nitrogen-nitrite $\left(\mu \mathrm{g} \quad \mathrm{NO}_{2}-\mathrm{N}\right)$ were determined weekly for both the inflow and outflow waters using a titration-test set (Aquanal-plus, Riedel-de Haen, Germany). With exception of total hardness which ranged between 148.73 and $187.46 \mathrm{mg} \mathrm{CaCO} / \mathrm{L}$, no drastic variations were recorded for other parameters during the experimental period.

\section{Experiment 2}

This experiment was carried out to study the effects of stocking density and feeding frequency. Three feeding frequencies (2, 3 and 4 times/day) were each tested at three stocking densities $(0.5$, 1 and 2 fish/L). Average fish weight and length at the initiation of the experiment were $0.38 \mathrm{~g}$ and $2.8 \mathrm{~cm}$, respectively. Each of the nine treatments was tested in triplicate for 12 weeks. The water flow rate was fixed at $3 \mathrm{~L} / \mathrm{min}$. for all treatments. Fish in all treatments were fed at a rate of $10 \%$ body weight per day during the first 6 weeks. This feeding level was reduced to $6 \%$ body weight per day during the rest of the study. Fish were weighed biweekly and feeding levels were adjusted accordingly. At the end of the experimental period, fish weight and length were recorded individually to the nearest $0.01 \mathrm{~g}$ and 0.01 $\mathrm{cm}$, respectively. The size variations of body weight and length were expressed as CV\%.

\section{Experiment 3}

Fish fry of the same parentage were reared together in a 70-L fiberglass tank for 8 weeks until size variations were evident. The fish were then harvested and sorted into three length groups (small, medium and large) ranging from 3.5 to 6 $\mathrm{cm}$. Body weight ranged from $1.04 \pm 0.21$ to $4.29 \pm 0.29 \mathrm{~g}$ (mean \pm s.d.). The initial CV\% of body weight were 20.27, 11.21 and $6.82 \%$ for the small, medium and large groups, respectively. A group of unsorted fish with an initial CV of $80 \%$ served as the mixed group. Each size group was reared in duplicate in 14-L rearing tanks at a rate of $0.5 \mathrm{fish} / \mathrm{L}$. Individual fish length and weight were recorded biweekly. Mean $\mathrm{CV} \%$ and mean specific growth rate, $\left(\left(\mathrm{SGR} \%=100\left[\left(\log _{\mathrm{e}}\right.\right.\right.\right.$ final body weight $\log _{\mathrm{e}}$ initial body weight) / (time, days)])), over the intervals between two samplings were calculated. The water flow rate in all rearing tanks was kept at $4.8 \mathrm{~L} / \mathrm{min}$. Fish in all groups were fed to satiation three times per day at 8.00, 13.00 and $18.00 \mathrm{~h}$.

\section{Statistical analysis}

The mean final body weights in each experiment were subjected to statistical 
comparisons using ANOVA. Mean differences between treatments were tested for significance $(\mathrm{P}<0.05)$ using Duncan's multiple range test (Duncan, 1950).

\section{Results}

\section{Experiment 1}

Variation in final body weights and length of different treatment groups are presented in Table 1 . The minimum ( $\mathrm{p}<$ 0.05 ) body size was observed in the group of fish stocked at 2 fish/L receiving the lowest water exchange rate (5 times/hr) with average total body length of $7.43 \mathrm{~cm}$ and average body weight of $9.15 \mathrm{~g}$. The highest $(\mathrm{p}<0.05)$ value was in the groups stocked at $0.5 \mathrm{fish} / \mathrm{L}$ receiving the highest water exchange rate (20 times/hr) with average total body length of $8.75 \mathrm{~cm}$ and average body weight of $14.40 \mathrm{~g}$. Coefficient of variation of body weight increased with increasing stocking rate in the two groups of fish receiving the lowest and intermediate water exchange rate (5 and 10 times/hr, respectively). This pattern was not evident in the groups of fish subjected to the highest water exchange rate (20 times/hr). No mortality was recorded in any of the experimental tanks.

\section{Experiment 2}

Variations in final individual body weights and relative sizes attained in this experiment are shown in Table 2. The minimum $(\mathrm{p}<0.05)$ size recorded was in the 2 fish/L group receiving 2 feeds /day with a body weight of $10.42 \mathrm{~g}$ and body length of $7.81 \mathrm{~cm}$. The maximum (p < 0.05 ) size was observed in the $0.5 \mathrm{fish} / \mathrm{L}$ group fed either 3 or 4 times /day with body weight of 13.44 or $13.41 \mathrm{~g}$, respectively and length of 8.73 or $8.66 \mathrm{~cm}$, respectively. In the groups of fish receiving 2 feedings/day, the CV\% of body weights increased with increasing stocking densities. However, in all other treatments groups receiving 3 and 4 feeds/day, the CV\% of body weights decreased with increasing stocking densities. No mortality was recorded in any of the nine treatments

\section{Experiment 3}

Contrary to the expectations that grading will reduce size variation, this phenomenon was reestablished within the homogeneous size distributions of small, medium and large individuals. In the mixed group, the CV\% of body weights was observed to decrease from $80 \%$ at the initiation of the experiment to $68.23 \%$ by the end (Table 3 ). While the CV\% values for the uniform size groups increased steadily, the values for the mixed group declined progressively. The SGR values for the uniform size groups increased at first (week 4) and thereafter decreased. In contrast, the values for the mixed group showed an inverse trend. The best $(\mathrm{p}<$ $0.05)$ SGR \%/day attained was in the mixed group. The lowest $(\mathrm{p}<0.05)$ value was observed in the group of large fish.

\section{Discussion}

It was observed that as fish, within each treatment group grew larger, some fish grew faster depressing the growth of others. This observation agrees with those reported by Refstie (1977) and Dambo and Rana (1992). At the lowest and intermediate water exchange rates ( 5 and 10 times/hr, respectively), size variation was not correlated to stocking levels. It is a generally accepted principal that increasing the number of fish (density) or reducing water turnover (lowering water quality) will adversely affect fish growth (Baker and Ayles, 1990). Water-borne growth inhibitors were cited as resulting in size variation in crowded tadpoles (Rose, 1960). Henderson-Arzapalo et al. (1980) suggested that in reused water (recirculating system) certain biochemical 
inhibitory factors released by fish and accumulated in the system could probably induce hypersensitivity and stress. In this study, the water quality detected in inflow, outflow and in the rearing tanks showed no sharp variations. The system was considered effective in removing metabolic products. Yet, the susceptibility of individuals to stresses resulting from the presence of even small amounts of metabolites is different. The explanation of such differences may be related to the type of social organization, behavioral conditioning and genetic background of

Table 1. Mean \pm s.d., CV\% and range of final total length and wet body weight of $O$. niloticus subjected to various stocking levels and water exchange rates

\begin{tabular}{|c|c|c|c|c|c|c|c|}
\hline \multirow{2}{*}{$\begin{array}{c}\text { Stocking } \\
\text { density } \\
\text { (Fish/L) }\end{array}$} & \multirow{2}{*}{$\begin{array}{c}\text { Water } \\
\text { turnover } \\
\text { (Times/h) }\end{array}$} & \multicolumn{3}{|c|}{ Total length $(\mathrm{cm})$} & \multicolumn{3}{|c|}{ Wet body weight } \\
\hline & & Mean \pm s.d. & CV\% & Range & Mean1 ( \pm s.d.) & CV\% & Range \\
\hline 0.5 & 5 & $8.26 \pm 1.26$ & 15.28 & $6.20-11.00$ & $10.56 \pm 4.75^{\mathrm{de}}$ & 44.93 & $4.23-22.16$ \\
\hline 1 & & $8.14 \pm 1.77$ & 21.65 & $2.25-11.90$ & $11.88 \pm 7.54^{\mathrm{b}}$ & 63.47 & $2.89-30.06$ \\
\hline 2 & & $7.43 \pm 1.60$ & 21.52 & $4.50-11.80$ & $9.15 \pm 6.19^{\mathrm{f}}$ & 67.61 & $1.73-32.32$ \\
\hline 0.5 & 10 & $8.31 \pm 1.49$ & 17.92 & $6.40-11.50$ & $11.38 \pm 6.09^{\mathrm{cd}}$ & 53.50 & $4.41-27.00$ \\
\hline 1 & & $8.22 \pm 1.64$ & 19.98 & $6.00-11.60$ & $10.86 \pm 6.53^{\mathrm{d}}$ & 60.09 & $3.38-24.82$ \\
\hline 2 & & $7.65 \pm 1.74$ & 22.73 & $4.60-14.00$ & $9.64 \pm 6.51^{\mathrm{e}}$ & 67.59 & $1.89-29.96$ \\
\hline 0.5 & 20 & $8.75 \pm 1.60$ & 18.30 & $6.10-11.50$ & $14.40 \pm 7.55^{\mathrm{a}}$ & 52.44 & $4.31-30.14$ \\
\hline 1 & & $8.26 \pm 1.74$ & 21.00 & $4.80-12.00$ & $11.58 \pm 7.79^{\mathrm{c}}$ & 64.71 & $2.19-33.87$ \\
\hline 2 & & $8.14 \pm 1.38$ & 16.99 & $5.80-11.50$ & $11.62 \pm 6.39^{\mathrm{bc}}$ & 55.02 & $3.89-30.17$ \\
\hline $\pm S E M$ & & & & & 0.389 & & \\
\hline
\end{tabular}

${ }^{I}$ Means within columns with different superscript are different $(P<0.05)$

Table 2. Mean \pm s.d. CV\% and range of final total length and wet body weight of O. niloticus subjected to various stocking densities and feeding frequencies

\begin{tabular}{|c|c|c|c|c|c|c|c|}
\hline \multirow{2}{*}{$\begin{array}{c}\text { Stocking } \\
\text { density } \\
\text { (Fish/L) }\end{array}$} & \multirow{2}{*}{$\begin{array}{l}\text { Feeding } \\
\text { frequency } \\
\text { (Times/h) }\end{array}$} & \multicolumn{3}{|c|}{ Total length (cm) } & \multicolumn{3}{|c|}{ Wet body weight } \\
\hline & & Mean \pm s.d. & CV\% & Range & $\operatorname{Mean}^{1}( \pm$ s.d. $)$ & CV\% & Range \\
\hline 0.5 & 2 & $8.26 \pm 1.29$ & 15.65 & $6.10-11.00$ & $11.33 \pm 5.93^{\mathrm{d}}$ & 52.33 & $4.44-28.20$ \\
\hline 1 & & $8.14 \pm 1.60$ & 19.60 & $5.90-11.80$ & $11.90 \pm 7.67^{\mathrm{cd}}$ & 64.44 & $3.52-33.44$ \\
\hline 2 & & $7.81 \pm 1.45$ & 18.51 & $5.20-12.40$ & $10.42 \pm 6.72^{\mathrm{e}}$ & 64.48 & $2.50-38.87$ \\
\hline 0.5 & 3 & $8.73 \pm 1.43$ & 16.41 & $6.60-11.50$ & $13.44 \pm 6.56^{\mathrm{a}}$ & 48.78 & $5.21-27.21$ \\
\hline 1 & & $8.52 \pm 1.63$ & 19.18 & $5.50-11.70$ & $13.00 \pm 6.23^{\mathrm{ab}}$ & 47.90 & $3.22-30.10$ \\
\hline 2 & & $8.48 \pm 1.92$ & 16.35 & $5.30-11.60$ & $12.62 \pm 5.99^{\mathrm{abc}}$ & 47.30 & $2.83-27.12$ \\
\hline 0.5 & 4 & $8.66 \pm 1.43$ & 16.55 & $6.50-10.80$ & $13.41 a \pm 6.88^{\mathrm{a}}$ & 51.28 & $3.94-24.57$ \\
\hline 1 & & $8.61 \pm 1.38$ & 16.02 & $6.00-11.25$ & $12.85 \pm 6.11^{\mathrm{ab}}$ & 47.58 & $4.19-27.71$ \\
\hline 2 & & $8.42 \pm 1.40$ & 16.57 & $5.20-10.90$ & $13.30 \pm 5.25^{\mathrm{bc}}$ & 44.91 & $2.40-24.52$ \\
\hline $\pm S E M$ & & & & & 0.307 & & \\
\hline
\end{tabular}


Table 3. Initial and final wet body weight, CV\% and final specific growth rate (SGR $\% /$ day) of different size groups of $O$. niloticus reared for 70 days

\begin{tabular}{|c|c|c|c|c|c|}
\hline \multirow{2}{*}{$\begin{array}{c}\text { Size of } \\
\text { Group } \\
\text { (Times/day) }\end{array}$} & \multicolumn{2}{|c|}{ Initial (Day 0) } & \multicolumn{2}{|c|}{ Final (Day 70) } & \multirow[b]{2}{*}{$\begin{array}{c}\text { SGR }^{1} \\
(\% / \text { Day })\end{array}$} \\
\hline & $\begin{array}{c}\text { Mean weight (g) } \\
\text { (Range) }\end{array}$ & CV\% & $\begin{array}{c}\text { Mean weight (g) } \\
\text { (Range) }\end{array}$ & CV\% & \\
\hline Small & $\begin{array}{c}1.04 \\
(0.75-1.24)\end{array}$ & 20.27 & $\begin{array}{c}6.55^{\mathrm{e}} \\
(3.45-10.98)\end{array}$ & 41.38 & $1.67 \mathrm{de}$ \\
\hline Medium & $\begin{array}{c}2.61 \\
(2.25-3.17)\end{array}$ & 11.21 & $\begin{array}{c}13.07^{\mathrm{d}} \\
(6.77-18.43)\end{array}$ & 34.57 & $1.85 d$ \\
\hline Large & $\begin{array}{c}4.29 \\
(3.86-4.77)\end{array}$ & 6.82 & $\begin{array}{c}21.07^{\mathrm{a}} \\
(12.39-38.97)\end{array}$ & 42.99 & $1.46 f$ \\
\hline Mixed & $\begin{array}{c}4.38 \\
(1.08-10.35)\end{array}$ & 80.00 & $\begin{array}{c}15.06^{\mathrm{bc}} \\
(5.35-35.8)\end{array}$ & 68.23 & $3.39 a$ \\
\hline
\end{tabular}

${ }^{1}$ Means within columns with different superscripts are different $(P<0.05)$

each individual within the population (Andrew, 1979). These stresses were probably compounded by those resulting from crowding. Barcellos et al. (1999) found that at high stocking densities of $O$. niloticus fingerlings, the resting plasma cortisol concentrations were high indicating an intense stress response resulting from social interactions.

Stocking density and feeding frequency had an effect on the size variation among individuals of initially uniform size. As the initial fish size was homogeneous and the daily supplies of food were ample, one would expect that the fish within each population would have slightly different final body sizes. However, the occurrence of overshoots was apparent in all treatment groups. Teng and Chua (1978) attributed such a phenomenon to social interactions between individuals and they further reported that once a social hierarchy within a population was established, the smaller fish were inhibited from feeding satisfactorily due to the physical presence of larger fish. Koebele (1985) claimed that disproportional food acquisition was the primary cause for the size hierarchy effect in Tilapia zillii. The dominant T. zillii were found to consume their entire ration while the subordinate fish did not. Alanara et al. (1998) studied the feeding behaviour of Arctic char Salvelinus alpinus within a dominance hierarchy and found that the subordinate fish suffered from stress and showed very little feeding activity and low growth.

The effect of stocking density on the growth of tilapia is controversial. Honer et al. (1987) reported that the growth of Saratherodon galilaeus was depressed at even low stocking levels and this was attributed to behavioural interaction. In contrast to this, Suresh and Lin (1992) found that red tilapia stocked at low densities showed better growth and that the agonistic fish behaviour was not affected by lowering densities. In this present study, when food availability was increased from 2 to 3 and 4 feedings/day, size variation of final body weights was slightly altered. This result is in agreement with that reached by Jobling (1985) who suggested that size variation within a population of 
Arctic char, Salvelinus alpinus L. was reduced or abolished if fish were allowed almost continuous access to food. The progressive increase in size variation with increasing stocking densities in the least frequently fed groups occurred presumably due to increasing stress associated with increased crowding which was compound by the effects of competition for food.

In the third experiment, when fish were graded and individuals of each size group were grown separately, size hierarchies were reestablished and steadily increased. This increase in size variation was accompanied by a notable decrease in specific growth rates of individuals. However, when different size groups were grown together, size variation declined with time, whilst specific growth rate manifested a progressive increase.

It is possible that the graded groups were subjected to some excessive stresses resulting from factors other than natural variability. Jobling (1982) suggested that within a population, size variation could result from natural variability and/or induced by competition or social interaction. Similarly, Purdom (1974) suggested that size hierarchies develop in the presence of excess food mainly due to the fact that smaller fish are inhibited from feeding in the presence of larger fish. However, it was observed in the present study that at each feeding period, smaller fish in all treatments were actively feeding without being seriously disturbed by the larger. When food was completely consumed, larger fish were observed to exhibit some sort of territoriality with some minor level of aggressive behavior ranging from a short chasing to fighting with lips. These observations exclude the possibility of competition for food as a direct cause of size hierarchy. Piper et al. (1992) stated that in any fish population there are individuals that are small because of their genetic background and they will remain smaller regardless of opportunities given them to grow faster. On the other hand, fish in this study were graded by selecting individuals of uniform body length with variability in initial body weights (Table 3 ). These initial variations might have led to the newly established size disparity in the graded groups. In juvenile steelhead trout, Salmo gairdneri and Atlantic salmo parr, Salmo salar it was well documented that a weight difference of as little as 5\% was sufficient to guarantee dominant status to the heavier of two individuals (Abbott et al., 1985; Huntingford et al., 1990).

In conclusion, this study revealed that size hierarchy, regardless of any manipulatory measures, is an inevitable phenomenon. Nevertheless, manipulation of water exchange rates and hence water quality was found to be an effective approach for minimizing the adverse effects of high stocking densities of juvenile $O$. niloticus. Grading is not recommended since size hierarchies will reestablish in a manner exceeding that of the original mixed population.

\section{References}

Abbott, J.C., R. L. Dunbrack, and C. D. Orr. 1985. The interaction between size and experience in dominance relationship of juvenile steelhead trout (Salmo gairdneri). Behaviour, 92: 241-253.

Alanara, A. 1997. Feeding behaviour and growth performance of fish within a dominance hierarchy. In: M. Jobling (ed.). The 1st. Workshop on Voluntary Food Intake in Fish. Aberdeen, UK.

Alanara, A., S. Winberg, E. Brannas, A. Kiessling, E. Hoglund, and U. Elofsson. 1998. Feeding behavior, brain serotonergic activity levels, and energy reserves of Arctic char (Salvelinus alpinus) within a dominance hierarchy. Can. J. Zool., 76(2): 212-220. 
Ambeker, E. E., and R.W. Doyle. 1990. Repeatability of relative size of individuals under communal stocking; implications for size-grading in aquaculture. In: Hirono, R. and Hanyo, L. (eds.). The South East Asian Fisheries Forum. Asian Fisheries Society, Manila.

Andrews, J.W., J. H. Knight, J.W. Page, Y. Matsuda, and E. E. Brown. 1972. Interactions of stocking density and water turnover on growth and food conversion of channel catfish reared in intensively stocked tanks. Prog. Fish-Cult., 33: 197-203.

Andrews, R.V. 1979. The physiology of crowding. Comp. Biochem. Physiol., 63: 1-6.

Bailey, J. K., R. L. Sunders, and M. I. Buzeta. 1980. Influence of parental smolt age and sea age on growth and smolting of hatchery-reared Atlantic salmon. Can. J. Fish Aquat. Sci., 37: 1379-1386.

Baker, R. F., and G. B. Ayles. 1990. The effect of varying density and loading level on the growth of Arctic charr (Salvelinus alpinus L.) and rainbow trout (Oncorhynchus mykiss). World Aquacult., 21: 58-61.

Balarin, J. D., and R. D. Haller. 1982. The intensive culture of tilapia in tanks, raceways and cages. In: Muir, J.F. and Roberts, R.J. (eds.). Recent Advances in Aquaculture. Croom Helm Ltd., London, pp. 266-345.

Barcellos, L. J.G., S. Nicolaiewsky, S. M.G. De Souza, and F. Lulhier. 1999. The effects of stocking density and social interaction on acute stress response in Nile tilapia Oreochromis niloticus (L.) fingerlings. Aquaculture Research, 30 (11-12): 887 - 892

Bjornsson, B. 1994. Effects of stocking density on growth rate of halibut (Hippoglossus hippoglossus L.) reared in large circular tanks for three years. Aquaculture, 123: 259-270.

Brett, J. R. 1979. Environmental factors and growth. In: Hoar, W.S., D.J. Randall, and J.R. Brett, (eds.). Fish Physiology, vol. 8. Academic Press, New York. NY. pp. 599675.

Cox, G. W. 1990. Laboratory Manual of General Ecology. Wm. C. Brown Publishers, Iowa, U.S.A.

Dambo, W. B., and K. J. Rana. 1992. Effect of stocking density on growth and survival of Oreochromis niloticus (L.) fry in the hatchery. Aquacult. Fish. Manage., 23: 7180.

Duncan, D. B. 1955. Multiple range and multiple F-test. Biometrics, 11:1-42.

Henderson-Arzapalo, A., R .R. Stickney, and D.H. Lewis.1980. Immune hypersensitivity in intensively cultured Tilapia species. Trans. Am. Fish. Soc., 109: 244-247.

Holm, J.C., T. Refstie, and S. B $\varnothing .1990$. The effect of fish density and feeding regimes on individual growth rate and mortality in rainbow trout (Oncorhynchus mykiss). Aquaculture 89: 225-232.

Honer, G., H. Rosenthal, and G. Kruner. 1987. Growth of juvenile Saratherodon galilaeus in laboratory aquaria. J. Aqua. Trop., 2: 5971.

Huntingford, F. A., N .B. Metcalfe, J. E. Thorpe, W. D. Graham, and C. E. Adams. 1990. Social dominance and body size in Atlantic salmon parr, Salmo salar. J. Fish Biol., 36: 877-881.

Jobling, M. 1982. Some observations on the effects of feeding frequency on the food intake and growth of plaice, Pleuronectes platessa L. J. Fish Biol., 20: 431-444. 
Jobling, M. 1983. Effects of social interactions on growth rates and conversion efficiency of Arctic charr, Salvelinus alpinus L. J. Fish Biol., 22: 577-584.

Jobling, M. 1985. Physiological and social constraints on growth of fish with special reference to Arctic charr, Salvelinus alpinus L. Aquaculture, 44: 83-90.

Keast, A., and J. M. Edie. 1985. Growth depensation in year-0 largemouth bass: The influence of diet. Trans. Am. Fish. Soc., 114: 204-213.

Kjartansson, H., S. Fivelstad, J. M. Thomassen, and M .J. Smith. 1988. Effects of different stocking densities on physiological parameters and growth of adult Atlantic salmon (Salmo salar L.) reared in circular tanks. Aquaculture, 73: 261-274.

Koebele, B. P. 1985. Growth and size hierarchy effect: an experimental assessment of three proposed mechanisms; activity differences, disproportional food acquisition, physiological stress. Environ. Biol. Fish., 12: 181-188.

Macintosh, D. J., and S. S. De Silva. 1984. The influence of stocking density and food ration on fry survival and growth in Oreochromis mossambicus and $O$. niloticus female $\mathrm{X} O$. aureus male hybrids reared in a closed recirculated system. Aquaculture, 41: 345-358.

Paller, M. H., and W .M. Lewis. 1987. Effects of diet on growth depensation and cannibalism among intensively cultured larval striped bass. Prog. Fish-Cult., 49: 270-275.

Piper, R. G., I .B. McElwain, L .E. Orme, J .P. McCraren, L.G. Fowler, and J.R. Leonard. 1992. Fish Hatchery Management. Fish and Wildlife Service, Washington, D.C.
Purdom, C. E. 1974. Variation in fish. In: Harden-Jones, F.R. (ed.) Sea Fisheries Research. Elek Science, London. pp. 347-355.

Refstie, T., and A. Kittelsen. 1976. Effect of density on growth and survival of artificially reared salmon. Aquaculture, 8: 319-326.

Refstie, T. 1977. Effect of density on growth and survival of rainbow trout. Aquaculture, 11: 329-334.

Render, B. D., and R. R. Stickney. 1979. Acclimation to ammonia by Tilapia aurea. Trans. Am. Fish. Soc., 108: 383388.

Rose, S. M. 1960. Feedback mechanism of growth control in tadpoles. Ecology, 41: 188-199.

Schreck, C. B. 1981. Stress and compensation in teleostean fishes: Response to social and physical factors. In: Pickering, A.D. (ed.). Stress and Fish. Academic Press, London. pp. 295-321.

Spotte, S. F. 1970. Fish and Invertebrate Culture. Wiley-Interscience, New York.

Suresh, A.V., and C. K. Lin. 1992. Effect of stocking density on water quality and production of red tilapia in a recirculated water system. Aqua. Eng., 11: 1-22.

Teng, S. K., and T. E. Chua. 1978. Effect of stocking density on the growth of estuary grouper, Epinephelus salmoides Maxwell, in floating net-cages. Aquaculture, 15: 273-287.

Thorpe, J. E. 1977. Bimodal distribution of length of juvenile Atlantic salmon under artificial rearing conditions. J. Fish Biol., 11: 174-184. 